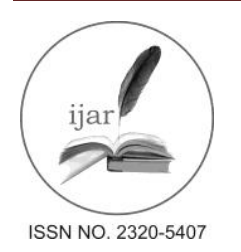

Journal homepage:http://www.journalijar.com
Journal DOI:10.21474/IJAR01

RESEARCH ARTICLE

\title{
INTERRELATIONSHIP BETWEEN STOCK RETURNS AND SELECTED MACROECONOMIC VARIABLES: AN EMPIRICAL STUDY.
}

INTERNATIONAL JOURNAL

OF ADVANCED RESEARCH

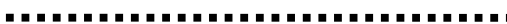

\section{Arushi Gaur ${ }^{1}$ and CA Dr. Priyanka Ostwal ${ }^{2}$.}

1. Research Scholar at Jamia Millia Islamia University, New Delhi.

2. Assistant Professor at Jagannath International Management School, Kalkaji, New Delhi.

\section{Manuscript Info}

Manuscript History:

Received: 19 May 2016

Final Accepted: 13 June 2016

Published Online: July 2016

Key words:

FII, Exchange Rate, Stock Return, Co-integration, Unit Root test, VECM.

*Corresponding Author

.............................

Arushi Gaur.

\begin{abstract}
The Indian Capital Market is said to be affected by various macroeconomic variables. The main purpose of this paper is to investigate the relationship between stock returns and two macroeconomic variables i.e. Exchange Rate and FII (Foreign Institutional Investment). Composite Index CNX Nifty has been considered as a proxy of Indian Capital Market. Dickey-Fuller Unit Root Test is applied to check the data for stationarity, Johansen Cointegration test has also been conducted to check whether the variables under consideration are cointegrated. Data was found to be stationary at first difference and variables were found to be cointegrated with each other. Since the variables are cointegrated, Vector Error Correction Model (VECM) has been used instead of classical Granger-Causality method and the results indicate that Exchange Rate Granger cause FII and Nifty both, and also FII Granger causes Nifty. No further causality was found between other variables.
\end{abstract}

\section{Introduction:-}

Indian Capital Market has witnessed major transformation and structural changes from the past two decades as a result of ongoing financial sector reforms. The major objective behind these reforms was to bring the Indian capital market up to a certain level comparable with international market. Towards this end, one of the major step taken is the introduction of computer based trading in two major stock exchanges in India i.e. BSE (Bombay Stock Exchange) and NSE (National Stock Exchange). NSE is one of the fastest emerging stock markets of India with high volatility. Rapidly increasing number of listed companies and high market capitalization value confirms this fact. Hence, Composite Index CNX Nifty has been considered as a proxy of Indian Capital Market performance in this paper.

The Capital Market of India is affected by various macroeconomic variables like FII, GDP, Exchange rate, FDI, Inflation etc. FII net investments in Indian Equity and debt market touched a record height of Rs. 18,106 crore in March 2016 with more than $90 \%$ of this investment in equity shares of Indian Companies. Further, India is expected to remain preferred market for foreign investors. Thus, one of the variables chosen to see relationship with movement of capital market is FII net investment. The other variable chosen for the purpose of investigating relationship with Indian capital market is currency exchange rate as changes in exchange rate directly affect the competitiveness of the companies at international level.

A lot of studies have already been conducted to see the relationship between various macroeconomic variables and stock market return, and most of the researchers have concluded that FIIs and exchange rate does not have a unit root at conventional level and also a positive Granger Causality test. In this paper, we have also tried to investigate empirically the relationship between macroeconomic variables (exchange rate and FII) and stock returns (NSE Nifty) in India. 
This paper is divided into following 6 segments: Segment 1 describes a brief introduction about the topic, Segment 2 discusses the available literature on the interrelationship among the three factors, Segment 3 describes the methodology used for the analysis, Section 4 describes the interrelationship among the three factors considered for this study based on econometric techniques of unit root, co-integration analysis and VECM; and in the end the last Segment concludes the paper.

\section{Literature Review:-}

Considerable amount of researches have already been conducted about the impact of macroeconomic variables on stock returns and stock prices in different economies using widespread econometric methods.

Fama (1981) concluded that there exists causality between stock prices and macroeconomic variables like inflation, exchange rate, interest rate and industrial production and that stock prices reflect these variables as well. Maysami and Koh (2000) and Choi et al. (1992) analyzed the changes in stock returns caused by rate of interest and exchange rate and concluded that both i.e exchange rate and interest rate are the determinants of the stock prices.

Frank and Young (1972) investigated the relationship between stock prices and exchange rates by employing six different exchange rates. The results found no statistically significant underlying relationship among the variables. Solnik (1987) concluded positive as well as negative relationship between stock returns and exchange rate movements for different time periods. Ma and Kao (1990) noticed a negative relationship whereas Oskooe and Sohrabian (1992) claimed a bi-directional Granger causality with no long-term relationship.

Many existing studies performed in Indian context found that the equity return has a significant as well as positive impact on the FII (Agarwal, 1997; Chakrabarti, 2001; and Trivedi \& Nair, 2003) but some also agreed on dual causality (to and fro) stating that foreign investors have the ability of playing like market makers given their volume of investments. Griffin (2004) found that foreign flows are significant predictors of stock returns for Korea, Taiwan, Thailand and India.

There are many researchers who pointed out a structural break in 1998-99 Asian crises when FII net investment went down, before and after which drastically different results are expected. Rajput and Thaker (2008) explained that no long run positive correlation exists between exchange rate and Stock Index in Indian context except for year 2002 and 2005. FII and Stock Index showed positive correlation, but failed to predict the future value. Takeshi (2008) analyzed the causalities between stock returns and Foreign Institutional Investment (FII) in India. Using the Cross Correlation Function approach the study reported unidirectional causality from stock returns to FII flows irrespective of the sample period in India whereas the reverse causality worked only post 2003.

Chakrabarti (2001) analyzed the relationship of FII with selected macroeconomic variables. The study found a regime shift in the determinants of FII flows to India with the domestic equity returns becoming the sole driver of these flows since Asian Crisis. Mukherjee, Bose, Coondoo (2002) tried to explore the impact of FII flows on the Indian equity market. The study used BSE Sensex, S\&P 500 and MSCI WI to represent risk whereas daily returns on the Rupee- Dollar exchange rate, short run interest rate and index of industrial production were selected as macroeconomic variables. Using Granger Causality Test the study concluded that FII flows to and from the Indian market tend to be caused by return in the domestic equity market and not vice versa. Regression analysis revealed that return in the Indian equity market was indeed an important factor that influences FII flows into the country. Sharma and Mahendru (2010) analyzed long term relationship between BSE Sensex and selected macroeconomic variables like change in exchange rate, foreign exchange reserve, inflation rate and gold prices. The study applied multiple regression equation models on the data for the period ranging from January 2008 to January 2009 and observed that there exists correlation among the variables. Ahmed (2008) investigated the causal relationship between stock prices and macro economic variables. The chosen variables were Index of industrial production, exports, foreign direct investment, money supply, exchange rate, interest rate, NSE Nifty and BSE Sensex in India. Applying Johansen's cointegration test, Granger causality test, BVAR model for variance decomposition and impulse response function the study observed differential causal links between macro-economic variables and stock indices.

To summarize, even though the theoretical explanation may look obvious at times, empirical results have shown a mixed tendency and existing literature is inconclusive on issue of causality. However, Cointegration and Granger causality test form integral part of methodology adopted by researchers across the globe. 
Objectives of Study:-

The main objective of this study is to investigate inter-relationship between stock return and selected macroeconomic variables. To achieve this objective, the following sub objectives have been chosen:

1. To check the data for stationarity

2. To find out the nature of long run relationship among stock return, FIIs, and Exchange rate

3. To find out the Causality between variables

Data Collection Methods:-

Daily nominal exchange rate data has been collected from official website of RBI (Reserve Bank of India) for April 1998 to March 2016. Daily closing values of Composite CNX Nifty Index has been taken from nseindia.com for the same period. FII (Net Investment) data from April 1998 to March 2016 has been collected from RBI Bulletin Archives. Since for FII, daily data was not available, hence monthly averages have been calculated for NIFTY and Exchange Rate.

Tools Used and Data Analysis:Augmented Dickey Fuller Test:-

This test is used to find out whether the variables of time series are stationary or non-stationary using an autoregressive model. It is used for large samples which uses the existence of a unit root as a null hypothesis. The results are presented in Table I

Table I:- Augmented Dickey-Fuller Test (ADF test)

Series: Exchange Rate, FII and Nifty Return

\begin{tabular}{|c|c|c|c|c|c|c|}
\hline & \multicolumn{3}{|c|}{ LEVEL } & \multicolumn{3}{|c|}{$\begin{array}{l}\text { FIRST DIFFERENCE } \\
\end{array}$} \\
\hline SYMBOL & $\begin{array}{l}\text { LAG } \\
\text { LENGTH }\end{array}$ & $\begin{array}{l}\text { ADF } \\
\text { STATISTICS }\end{array}$ & $\begin{array}{l}\text { P- } \\
\text { VALUE }\end{array}$ & $\begin{array}{l}\text { LAG } \\
\text { LENGTH }\end{array}$ & $\begin{array}{l}\text { ADF } \\
\text { STATISTICS }\end{array}$ & P-VALUE \\
\hline Exchange Rate & 1 & -0.135142 & 0.9429 & 0 & -13.64738 & $0.0000 *$ \\
\hline FII & 1 & -10.02139 & $0.0000 *$ & $\mathbf{0}$ & -11.97067 & $0.0000 *$ \\
\hline NIFTY & 1 & -0.272712 & 0.9255 & $\mathbf{0}$ & -15.05902 & $0.0000 *$ \\
\hline
\end{tabular}

Exogenous: Constant, Lag Length: Automatic based on SIC, MAXLAG=14

*MacKinnon (1996) one-sided p-values. Denotes rejection of null hypothesis at 5\%

Deterministic Terms: Intercept

ADF statistics in table-1 clearly suggests acceptance of null hypothesis in case of Exchange Rate and Nifty data series at level. Thus, the variables Exchange Rate and Nifty are non-stationary in nature at level. But after First difference all the variables (Exchange Rate, FII, and Nifty) become stationary of the same order.

\section{Johansen Co-integration Test:-}

Cointegration is a statistical property of time series variables. It is the test for cointegration that allows for more than one cointegration relationship in large samples. The test shows two statistics (Trace and Maximum Eigen) values that determine the number of equations which shows the existence and non-existence of co-integration.

Table II:-Johansen Co-integration TestUnrestricted Co integration Rank Test (Trace).

Series Exchange Rate, FII, Nifty Return

\begin{tabular}{|l|l|l|l|l|}
\hline Hypothesized & & Trace & $\mathbf{0 . 0 5}$ & \\
\hline No. of CE(s) & Eigenvalue & Statistic & Critical value & Prob.** \\
\hline None & 0.135907 & 39.81455 & 29.79707 & $0.0025^{*}$ \\
\hline At most 1 & 0.030838 & 8.846748 & 15.49471 & 0.3797 \\
\hline At most 2 & 0.010352 & 2.206111 & 3.841466 & 0.1375 \\
\hline
\end{tabular}

Trace test indicates there is one cointegration equation at the 0.05 level

*Denotes rejection of the hypothesis at the 0.05 level

**MacKinnon-Haug-Michelis (1999) p-values

Analysis of trace statistics and critical value from table II clearly indicates existence of one cointegration equation as the critical value of 29.79707 is less than the Trace Statistics of 39.81455 when No. of CE is 0. Thus we conclude that there exists a long term relationship between the variables. 


\section{Vector Error Correction Model:-}

Since there exists at least one cointegration equation between the variables under consideration, hence the classical Granger-Causality Test cannot be used. The results of table-2 suggest existence of causal relationship in either one direction or both the directions among two or more variables but it is not confirmed by Johansen Cointegration test. The required information can be obtained by using VECM (Vector Error Correction Model). This model checks the data for causality among variables. The study assumes all variables as endogenous. The result of VECM is explained as below (Table III):

Table III:-Vector Error Correction Estimates.

Series Exchange Rate, FII, Nifty Return

\begin{tabular}{|l|l|l|l|l|}
\hline $\begin{array}{l}\text { Dependent } \\
\text { Variable }\end{array}$ & FIIs & Nifty & Exchange Rate & ECT $_{\text {t-1 }}$ \\
\hline & \multicolumn{3}{|l|}{ F-Statistics (P-Values) } & t-statistics \\
\hline FII & - & 0.26945 & $0.00111^{*}$ & $-7.30756^{* *}$ \\
\hline Nifty & $0.02593^{*}$ & - & $0.00040^{*}$ & 0.63038 \\
\hline Exchange Rate & 5.67975 & 21.1425 & - & 0.28991 \\
\hline
\end{tabular}

*Rejection of null hypothesis at 0.05 Level

The analysis of the above table suggests a unidirectional short term causality from Exchange rate to FII and Nifty both; the same result (unidirectional causality) was found in case of FII and Nifty (FII Granger Cause Nifty). The other variables in the study failed to show any causality among them. A long term causality relationship also exists for FII running from Nifty and Exchange Rate as the error correction term is highly significant for FII at 0.05 level.

\section{Conclusion:-}

The study examined the existence of interrelationship between the Indian Stock Market and selective Macroeconomic variables using evidences from Indian Market. Augumented Dickey Fuller Test (Unit Root Test) was conducted to check the stationarity of data and the empirical result suggested the stationarity of data at first difference. Further, the study used Johansen Cointegration tool to check whether the variables under consideration are cointegrated and the analysis concluded the existence of a long term relationship between the variables. Since at least one cointegration equation existed between the variables, Classical Granger-Causality Test could not be used. To find out the causality between the variables VECM (Vector Error Correction Model) has been used and the result suggested a unidirectional short term causality from Exchange rate to FII and Nifty both; The same result (unidirectional causality) is found in case of FII and Nifty (FII Granger Cause Nifty). The results also suggested existence of long term causality relationship for FII running from Nifty and Exchange.

\section{References:-}

1. Ahmed, S. (2008), “Aggregate economic variables and stock markets in India. International Research Journal of Finance and Economics", Vol 14, pp 141-164.

2. Babu M. Suresh, Prabheesh K.P (2008), "Causal relationships between Foreign Institutional Investments and stock returns in India", Int. Journal of Trade and Global Markets, Vol. 1, Issue No. 3, pp. 259-265.

3. Bhattacharya Basabi (2012), "Causal relationship between Stock market and Exchange rate, Foreign Exchange Reserves and value of trade balance: An Empirical Analysis", Money and Finance Conference Proceedings, Department of Economics, Jadavpur University, Kolkata- 700032, India

4. Chakrabarti, R. (2001). "FII flows to India: Nature and causes. Money and Finance", Vol 2 Issue 7.

5. Fama E. F. (1981), "Stock returns, real activity, inflation, and money", The American Economic Review, Vol. 71, Issue No. 4, pp. 545-565.

6. Franck, P. And Young, A., (1972), "Stock price Reaction of Multinational Firms to Exchange Realignments", Financial Management 1, pp. 66-73.

7. Ilhan Ozturk, Huseyin Kalyoncu (2007), "Foreign Direct Investment and Growth: An Empirical Investigation Based on Cross-Country Comparison", EconomiaInternazionale, Volume 60, Issue No. 1, pp. 75-82.

8. Kerry, Patterson (2000) "An Introduction to Applied Econometrics: A Time Series Approach." New York: St. Martin's Press (2000).

9. Lean HH et al.(2011), "Exchange rate and Stock price interaction in major Asian markets: evidence for individual countries and panels allowing for structural breaks", The Singapore Economic Review, Issue 56 (02), 
pp. $255-277$.

10. Li Yaqiong\& Huang Lihong(2008) "On the Relationship between stock return and exchange rate: evidence on China", Conference Proceedings, $19^{\text {th }}$ Annual Conference of the CEA (UK), pp. 1-2.

11. Muhammad Naeemet et al.(2000), "Stock Prices and Exchange Rates: Are they Related? Evidence from South Asian Countries", The Pakistan Development Review, Issue 1, pp. 535-550.

12. Matthew Kofi,Ocran (2010), "South Africa and United States stock prices and the Rand/Dollar exchange rate", South African Journal of Economic and Management Sciences, Vol. 13, Issue No. 3, pp. 362-375.

13. Maysami et al. (2000), "A vector error correction model of the Singapore stock market", International Review of Economics \& Finance, Vol. 9, Issue No. 1, pp. 79-96.

14. Rai Kulwant, Bhanumurthy N. R. (2004), "Determinants of Foreign Institutional Investment in India: The role of Return, Risk and Inflation", The Developing Economies, Vol No. 42, Issue No. 4, pp. 479-493.

15. Rajput et al. (2005) "Exchange Rate, FII and Stock Index Relationship in India", Vilakshan, XIMB Journal of Management, Issue No. 5.1, pp. 43-56.

16. Solnik B. (1987), "Using financial prices to test exchange rate models: A note", The Journal of Finance, Vol. 1, Issue No. 42, pp. 141-149.

17. Shew, Jeffrey Allen (2008), "Causality Relationship between Foreign Exchange Rates and Stock Market Close: Evidence in Singapore", Bryant Economic Research Paper, Vol. 1, Issue No. 11, pp. 1-11.

18. Sharma G. D., Mahendru, M. (2010), "Impact of macro-economic variables on stock prices in India. Global Journal of Management and Business Research", Vol 10, Issue 7.

19. Suganthi P., Dharshanaa C. (2014), "Interrelationship between FII and Stock Market and their Causal Relationship with Selected Macroeconomic Variables in India", TSM Business Review, Vol 1, Issue No. 2, pp. 29.

20. Takeshi Inoue (2008), "The causal relationships in mean and variance between stock returns and Foreign institutional investment in India", The Journal of Applied Economic Research, IDE discussion paper no.180, http://mar.sagepub.com/content/3/4/319.short

21. Vardar G.et al. (2008), "Effects of interest and exchange rate on volatility and return of sector price indices at Istanbul stock exchange", European Journal of Economics, Finance and Administrative Sciences, Issue 11, pp.1-10.

22. Gujarati D.N., 2005. Basic Econometrics, McGraw-Hill International, New York, Fourth Edition.

23. Johnston J and John Dinardo, 1997. Econometric Methods, McGraw-Hill International, MGHISE, 4th Edition.

24. National Stock Exchange, www.nseindia.com,data extracted on $25^{\text {th }}$ May 2016.

25. Reserve Bank of India website, https://rbi.org.in/Scripts/BS_PressReleaseDisplay.aspx, data extracted on $25^{\text {th }}$ May 2016. 